\title{
Análisis genético para vida productiva en ganado Holstein de México
}

\author{
Genetic analysis of productive life in Holstein cattle \\ in Mexico
}

\author{
José R. Abadía Rojasa, Felipe de Jesús Ruíz Lópezb, Vicente E. Vega Murilloc, \\ Hugo H. Montaldod
}

\begin{abstract}
RESUMEN
Se usó la metodología de análisis de supervivencia con un modelo de riesgos proporcionales de Weibull para estudiar la duración de vida productiva funcional (DVPF) de ganado Holstein en México, usando un modelo padre-abuelo materno con el software Survival Kit V3.12. La DVPF se calculó como el número de días entre la fecha de primer parto y la fecha de desecho o censura, con un crédito máximo de $\mathbf{3 0 5}$ días por lactación. Los datos analizados se obtuvieron de la Asociación Holstein de México. El archivo final constó de 36,507 registros para DVPF de vacas que parieron por primera vez entre 1995 y 2008. El modelo incluyó la función de riesgo basal de Weibull y los siguientes efectos fijos: edad al primer parto, número de lactación por fase de lactación con cortes en los días 29, 249 y 305 y nivel de producción estandarizado con 10 clases con cambios en cada lactación, incluidas como variables tiempo dependientes y los efectos aleatorios de hato-año de parto y efectos genéticos de padre y abuelo materno. El porcentaje de censura fue de $\mathbf{2 5 . 5 4} \%$. Todos los efectos fijos analizados fueron significativos $(P<0.0001)$ y tuvieron una influencia importante en el riesgo de desecho de los animales. Las heredabilidades calculadas en escalas logarítmica, original, efectiva y equivalente resultaron de $0.08,0.13,0.12$ y 0.10 respectivamente, indicando que este carácter se puede integrar efectivamente a los programas de mejoramiento genético como se ha hecho en otras poblaciones de ganado Holstein.
\end{abstract}

PALABRAS CLAVE: Análisis de supervivencia, Modelo de Weibull, Variable tiempo dependiente, Heredabilidades.

\begin{abstract}
Methodology survival analysis model with Weibull proportional hazards was used to study Holstein cattle duration of functional productive life (FPL) in Mexico, using a model sire-maternal grandsire with Survival Kit V3.12 software. The FPL was calculated as the number of days between the date of first calving and the date of culling or censored, with a maximum credit of $\mathbf{3 0 5} \mathrm{d}$ per lactation. The FPL was defined as the length of time between first calving and date of culling or death and a maximum of $\mathbf{3 0 5}$ d lactation. The data analyzed were obtained from the Holstein Association of Mexico. The final file consisted of 36,507 records for FPL of cows that calved for the first time between 1995 and 2008. The model included baseline hazard function of Weibull and the following fixed effects: age at first calving, lactation number by stage of lactation with cuts 29, 249 y 305 and standardized production level, with 10 classes with changes in each lactation period included as dependent variables and random effects of herd-year of calving and genetic effects of sire and maternal grandsire. Percentage of censored data was $25.54 \%$. All analyzed fixed effects were significant $(P<0.0001)$ and had a significant risk of animal culling influence. The heritability calculated logarithmic, original, effective and equivalent scales were $0.08,0.13,0.12$ and 0.10 respectively, indicating that this character can effectively integrate breeding programs as has been done in other locations of Holstein cattle.
\end{abstract}

KEY WORDS: Survival analysis, Weibull model, Variable time dependent, Heritability.

Recibido el 25 de junio de 2013. Aceptado el 15 de agosto de 2013.

a Facultad de Medicina Veterinaria y Zootecnia de la Universidad Veracruzana. Miguel Ángel de Quevedo s/n esq. Yáñez Col. Unidad Veracruzana, 91710 Veracruz, Ver. México.

b Centro Nacional de Investigación Disciplinaria en Fisiología y Mejoramiento Animal, INIFAP. México. ruiz.felipe@inifap.gob.mx. Correspondencia al segundo autor.

c Centro de Investigación Regional Golfo Centro, INIFAP. México.

d Universidad Nacional Autónoma de México. México.

Este trabajo es parte de la tesis de maestría del primer autor.

Esta investigación fue apoyada por la Asociación Holstein de México, el CONACYT, el CONARGEN y el Programa Nacional de Mejoramiento Genético HolsteinSAGARPA. 


\section{INTRODUCCIÓN}

La longevidad en bovinos lecheros puede medirse como el tiempo que transcurre desde el primer parto hasta el desecho o muerte del animal, lo que también es conocido como duración de vida productiva (DVP). La DVP de una vaca productora de leche puede estar determinada por su nivel de producción, fertilidad, salud, etc. De particular interés es el proceso de desecho involuntario, es decir, el desecho por causas fuera del control del ganadero como son enfermedades o problemas reproductivos, y cuando este proceso incluye el nivel de producción de la vaca en el modelo con el fin de corregir para el desecho voluntario; esta característica es conocida como duración de vida productiva funcional (DVPF) $(1,2)$.

El uso de técnicas de análisis de supervivencia para estudiar la DVPF tiene la ventaja de que permite incorporar covariables dependientes del tiempo, utilizar registros incompletos (censurados), analizar grandes bases de datos y aplicar modelos mixtos que permiten a su vez realizar evaluaciones genéticas nacionales, aunque la forma de evaluar y los modelos utilizados varían de acuerdo a las circunstancias de utilización $(3,4,5)$.

En estudios previos a partir de información en México, se analizó el efecto de nivel de producción de leche sobre la DVP, con base en un estimador Kaplan-Meier y un modelo de regresión de Weibull(6), o se analizó la longevidad como la capacidad de permanencia a los 48 meses y como duración de vida productiva hasta la tercera lactación, empleando modelos lineales mixtos(7). Sin embargo, no se han realizado estudios que aborden el uso de técnicas de supervivencia en la predicción de valores genéticos en la población Holstein de México bajo control de producción. Esto resulta necesario para el desarrollo de sistemas eficaces de evaluación genética para esta característica en toros de inseminación artificial usados en

\section{INTRODUCTION}

Longevity in dairy cows can be measured as the time from first parturition to animal cull or death, an interval called productive life (PL). In a producing dairy cow, PL is influenced by production level, fertility, health, etc. Of particular interest is involuntary culling, that is, for reasons beyond the control of the farmer (e.g. disease or reproductive problems). This process is known as functional productive life (FPL) when it includes cow production level in the model in an effort to correct for voluntary culling $(1,2)$.

The study of FPL using survival analysis techniques allows incorporation of timedependent covariables, use of incomplete (censured) records, analysis of large data bases and application of mixed models that permit national level genetic evaluations. However, the way these evaluations are done and the models used to do so, can vary depending on circumstances $(3,4,5)$.

Previous studies using data from Mexico have analyzed the effect of milk production level on PL either based on a Kaplan-Meier estimator and a Weibull regression model(6), or using mixed linear models and treating longevity as the ability to remain in the herd at $48 \mathrm{mo}$ of age with a PL extending to the third lactation(7). No studies have been done, however, addressing the use of survival analysis in predicting genetic values in a Holstein population in Mexico under milk recording. Genetic values are needed to develop effective genetic improvement systems for this trait on artificial insemination bulls used in Mexico. This trait is vital to genetic improvement of dairy cows for reasons of economy (e.g. production system sustainability) and animal health (improved PL reduces risk of disease)(6,7).

The present study objectives were to estimate heritabilities and predict genetic values for FPL by applying a proportional risk model with a 
México, dado que se trata de una característica de gran importancia para la mejora genética de los bovinos productores de leche, considerando tanto aspectos económicos, como de la sostenibilidad de los sistemas de producción e incluso del bienestar animal, al contribuir el mejoramiento de la DVP por una reducción de los riesgos de enfermedad $(6,7)$.

Los objetivos del presente estudio fueron estimar heredabilidades y predecir valores genéticos para DVPF, aplicando una distribución Weibull y utilizando un modelo de riesgos proporcionales en ganado Holstein de México.

\section{MATERIAL Y MÉTODOS}

Se utilizó información de vacas Holstein que parieron por primera vez entre 1995 y 2008, proporcionada por la Asociación Holstein de México a partir del control lechero oficial y del registro genealógico. La DVP se calculó como el número de días entre la fecha de primer parto y la fecha de desecho o censura, con un crédito máximo de 305 días por lactación y definiéndose como censurados los registros de animales que se vendieron vivos para producción a otros ranchos, aquéllos de vacas vivas cuando el hato dejó de estar en control de producción, o lactaciones no consecutivas de un mismo animal. Para obtener una mejor precisión y asegurar la convergencia de los modelos se eliminaron lactaciones: con producciones de leche estandarizadas fuera del intervalo de 2,500 y $17,000 \mathrm{~kg}$ correspondientes a los porcentiles 1 y 99 respectivamente por considerarlas anormales; datos de vacas sin información de primeras lactaciones; datos de vacas con edades al primer parto menores de 17 meses y datos de vacas hijas de sementales con menos de cinco hijas. El archivo final constó de 36,507 registros para DVP.

Las estimaciones de los parámetros y las predicciones de los valores genéticos se calcularon usando el programa Survival Kit V3.12(8,9), empleando un modelo de riesgos
Weibull distribution in a Holstein population in Mexico.

\section{MATERIAL AND METHODS}

Data was for Holstein cows with first parturition between 1995 and 2008, and was provided by the Mexican Holstein Association (Asociación Holstein de México) from official milk recording and genealogical records. Productive life (PL) was calculated as the number of days between date of first parturition and date of culling or censure. Maximum credit for lactation was $305 \mathrm{~d}$ and censured animals were defined as records of cows sold to other farms for production, of live cows in a herd when its production stopped being recorded, or of cows with non-consecutive lactations. For greater accuracy, and to ensure model convergence, lactations were eliminated for any one of four reasons: 1) Abnormal standardized milk production, i.e. $<2,500 \mathrm{~kg}$ (1st percentile) or $>17,000 \mathrm{~kg}$ (99th percentile); 2) No data for first lactation; 3) First lactation at $<17$ mo of age; and 4) Daughters of sires with less than five daughters. The final database consisted of $36,507 \mathrm{PL}$ records.

Parameter estimations and genetic value predictions were calculated with the Survival Kit ver. 3.12 program $(8,9)$. A sire-maternal grandsire proportional risk model was used in which a Weibull distribution was assumed for the basic risk function. The FPL analysis model was:

$h(\mathrm{t})=\lambda \rho(\lambda t)^{\rho-1} \exp \left\{H Y_{j}(t)+A P_{k}(t)+L P_{l m}(t)+\right.$ $\left.M P L_{n}(t)+S_{q}+0.5 s_{m g}\right\}$

In this model, $h(t)$ represents a cow elimination risk in time $t$. The basic risk function is $\lambda \rho(\lambda t)^{\rho-1}$, where $\rho$ is the distribution shape parameter and $\lambda$ corresponds to the distribution scale parameter. $H Y_{j}(t)$ is the random effect of the $j$-th herd-year of first parturition. This had a log-gamma function associated with parameter $\gamma$, included to acknowledge that animal elimination is a decision made by comparing animals within similar or contemporaneous 
proporcionales padre-abuelo materno, en el que se supuso una distribución de Weibull para la función de riesgo basal. El modelo de análisis (DVPF) fue el siguiente:

$h(\mathrm{t})=\lambda \rho(\lambda t)^{\rho-1} \exp \quad\left\{H Y_{j}(t)+A P_{k}(t)+L P_{l m}(t)+\right.$ $\left.M P L_{n}(t)+S_{q}+0.5 s_{m g}\right\}$

Donde: $h(t)$, representa el riesgo de eliminación de una vaca en el tiempo t. $\lambda \rho(\lambda t)^{\rho-1}$ es la función de riesgo basal, donde $\rho$ es el parámetro de forma de la distribución y $\lambda$ corresponde al parámetro de escala de la distribución. $H A_{j}(t)$, es el efecto aleatorio del j-ésimo hato-año de primer parto, asociado a una distribución log-gamma con parámetro $\gamma_{\text {r }}$ incluido para reconocer que la eliminación de un animal es una decisión que se toma al comparar animales dentro de grupos similares o contemporáneos, su efecto no se explica en este estudio(8). $E P_{k}(t)$ es el efecto de la k-ésima edad al primer parto en meses con cuatro clases (1 ( $\leq 23$ meses), 2 (24,25 meses), 3 (26,27 meses) y 4 ( $\geq 28$ meses). $F L_{l m}(t)$ es el efecto tiempo-dependiente de la l-ésima fase de la lactación con cambios en los tiempos: $1-29,30-249$ y 250-305 días después del parto, dentro de la m-ésima lactación: $1,2,3, \geq 4$, suponiendo que el riesgo no cambia dentro de cada segmento. $N P_{n}(t)$ es el efecto del $n$-ésimo nivel de producción dentro del hato-año de primer parto. Los niveles de producción se obtuvieron ordenando los registros productivos en forma ascendente para que acto seguido, se obtuviera la media y la desviación estándar. Finalmente con base en la distribución normal se calcularon los deciles que representaron el nivel de producción para cada lactación, con 10 clases, siendo el nivel de producción 1 el más bajo y el nivel 10 el más alto. Padre $\left(S_{q}\right)$ y abuelo materno $\left(S_{a m}\right)$, son los efectos aleatorios de los ancestros y para su análisis se agruparon en un solo vector $\mathrm{S}$ suponiendo que siguen una distribución normal multivariada con matriz de varianzas y covarianzas $A \sigma_{s}^{2}$. groups, the effect of which is not explained in this study(8). $A P_{k}(t)$ is the $k$-th effect of age at first parturition in months, divided into four categories $(1, \leq 23 \mathrm{mo} ; 2,24-25 \mathrm{mo} ; 3,26-27$ mo; and $4, \geq 28 \mathrm{mo}) . L P_{l m}(t)$ is the timedependent effect of the 1 -th lactation phase, divided into three times (1-29, 30-249 and 250$305 \mathrm{~d}$ after parturition), within the $m$-th lactation (i.e. 1, 2, 3 and $\geq 4$ ), assuming that risk does not change within each segment. $M P L_{n}(t)$ is the effect of the $n$-th milk production level within herd-year of first parturition; production levels were calculated by organizing production records in ascending order to generate the mean and standard deviation. Finally, deciles were calculated based on normal milk production to represent production level per lactation, divided into ten categories, 1 being the lowest and 10 the highest. Sire $\left(s_{q}\right)$ and maternal grandsire $\left(S_{m g}\right)$ were random ancestor effects and were grouped into one vector $(s)$ for analysis, assuming that they followed a normal multivariate distribution with $A \sigma_{s}^{2}$ as the variance - covariance matrix.

Heritabilities were calculated on a logarithmic scale $\left(h_{\mathrm{log}}^{2}\right)(4,9)$, that is, the transformation of time $(T)$ in a logarithmic scale, and in the original scale $\left(h_{0}^{2}\right)$, following $\operatorname{Ducrocq}(10)$ as described in Chirinos et a(4):

$$
h_{\mathrm{log}}^{2}=\frac{4 \operatorname{var}(s)}{\left(\Psi^{1} \gamma_{h}+\frac{5}{4} \operatorname{var}(s)+\frac{\pi^{2}}{6}\right)}
$$

Where: $\Psi^{1} \gamma_{h}$, is the trigamma function evaluated in $\gamma_{h} ; \operatorname{var}(\mathrm{s})$ is sire's variance; and $\frac{\pi^{2}}{6}$ is the extreme value distribution's variance.

$h_{o}^{2}=\left[\exp \left\{\frac{1}{\rho} v\right\}\right]^{-2} h_{\log }^{2} h_{o}^{2}=\left[\exp \left\{\frac{1}{\rho} v\right\}\right]^{-2} h_{\log }^{2}$ 
Las heredabilidades sobre una escala logarítmica $\left(h_{\log }^{2}\right)(4,9)$, es decir, la transformación de la variable tiempo $(T)$ en una escala logarítmica y en la escala original $\left(h_{\mathrm{o}}^{2}\right)$, se calcularon siguiendo la metodología de Ducrocq(10) mencionada por Chirinos et $a(4)$ de la siguiente manera:

$$
h_{\log }^{2}=\frac{4 \operatorname{var}(s)}{\left(\Psi^{1} \gamma_{h}+\frac{5}{4} \operatorname{var}(s)+\frac{\pi^{2}}{6}\right)}
$$

Donde: $\Psi^{1} \gamma_{h}$, es la función trigamma evaluada en $\gamma_{h}, \operatorname{var}(\mathrm{s})$ es la varianza del padre, y $\frac{\pi^{2}}{6}$ es la varianza de la distribución del valor extremo.

$$
h_{o}^{2}=\left[\exp \left\{\frac{1}{\rho} v\right\}\right]^{-2} h_{\log }^{2} h_{o}^{2}=\left[\exp \left\{\frac{1}{\rho} v\right\}\right]^{-2} h_{\log }^{2}
$$

Donde: $v$ es la esperanza de la distribución del valor extremo: $v=$ negativo del número de Euler; $\rho$ es la forma de la función de riesgo basal; $h_{\log }^{2}$ es la heredabilidad sobre una escala logarítmica.

Con el objeto de verificar si la expresión de la heredabilidad en la escala original dependía de los estimadores de la distribución Weibull como lo mencionaron Chirinos et al(4) y $\operatorname{Ducrocq}(10)$, la heredabilidad efectiva y equivalente se calculó como:

$$
\begin{aligned}
& h_{e f}^{2}=\frac{4 \operatorname{var}(s)}{\left(\Psi^{1} \gamma_{h}+\operatorname{var}(s)+1\right)} \\
& h_{e(t)}^{2}=\frac{4 \operatorname{var}(s)}{\left(\Psi^{1} \gamma_{h}+\operatorname{var}(s)+1 / p\right)}
\end{aligned}
$$

Donde $p$ es la proporción de registros completos; esta última se aplica en este estudio.
Where: $v$ is the negative Euler number; $\rho$ is the shape of the basic risk function; and $h_{\mathrm{log}}^{2}$ is the heritability on a logarithmic scale.

To confirm that the original scale heritability expression depended on the Weibull distribution estimators as reported elsewhere $(4,10)$, effective and equivalent heritability were calculated as follows:

$$
\begin{aligned}
& h_{e f}^{2}=\frac{4 \operatorname{var}(s)}{\left(\Psi^{1} \gamma_{h}+\operatorname{var}(s)+1\right)} \\
& h_{e(t)}^{2}=\frac{4 \operatorname{var}(s)}{\left(\Psi^{1} \gamma_{h}+\operatorname{var}(s)+1 / p\right)}
\end{aligned}
$$

Where $p$ is the proportion of complete records, which is applied in the present study.

The reliability of the predicted genetic values for sires was calculated based on records of their daughters(10):

$$
R=\frac{N h_{e}^{2}}{(N-1) h_{e}^{2}+4}
$$

Where: $R$ is the genetic value reliability of sires; $N$ is the number of daughters with recorded FPL; and $h_{e}^{2}$ is the equivalent heritability.

Model effects were tested with a partial likelihood ratio test, and estimation was done using the maximum likelihood method(8).

\section{RESULTS}

In the total sample of $36,507 \mathrm{FPL}$ records, censoring rate was $25.5 \%$, cows had an average of 2.23 lactations, average time to cull/ death was $615 \mathrm{~d}$ and average time to censoring was $731 \mathrm{~d}$. The data included the daughters of 1,116 sires and 1,684 maternal grandsires.

In terms of relative risk (average risk $=1$ ) under the influence of environmental and genetic 
Las confiabilidades de los valores genéticos predichos de los padres se calcularon con base en los registros observados de sus hijas, de la manera siguiente(10):

$$
R_{.}=\frac{N h_{e}^{2}}{(N-1) h_{e}^{2}+4}
$$

Donde: $R$ es la confiabilidad de los valores genéticos del padre con $N$ hijas, $N$ es el número de hijas con DVPF observada y $h_{e}^{2}$ es la heredabilidad equivalente.

Los efectos del modelo se probaron por medio del test de razón de verosimilitudes de manera parcial y la estimación se efectuó por el método de máxima verosimilitud(8).

\section{RESULTADOS}

El porcentaje de censura en los 36,507 registros de DVPF fue de $25.5 \%$ y los tiempos promedio al desecho/muerte o censura fueron de $615 \mathrm{y}$ 731 días, respectivamente, con un promedio de 2.23 lactaciones. Los datos incluyeron información de hijas de 1,116 padres y 1,684 abuelos maternos. effects, the youngest cows (categ. 1, $\leq 23 \mathrm{mo}$ ) had a greater culling risk than the cows in lactation categories 2, 3 and $\geq 4$. Age at first parturition apparently had no effect on FPL (Table 1, Figure 1).

Cuadro 1. Proporción y número de observaciones por fase dentro de lactación

Table 1. Proportion (\%) and number (N) of observations by phase within lactation categories and phases

\begin{tabular}{ccrr}
\hline Lactation & & & \\
Category & Phase (days) & \multicolumn{1}{c}{$\%$} & $\mathrm{~N}$ \\
\hline \multirow{3}{*}{1} & $1-29$ & 0.67 & 181 \\
& $30-249$ & 11.70 & 3182 \\
& $250-365$ & 22.74 & 6181 \\
2 & $1-29$ & 1.30 & 353 \\
& $30-249$ & 18.00 & 4894 \\
& $250-365$ & 14.18 & 3856 \\
3 & $1-29$ & 1.24 & 337 \\
& $30-249$ & 12.12 & 3296 \\
& $250-365$ & 8.95 & 2434 \\
4 & $1-29$ & 0.77 & 209 \\
& $30-249$ & 6.33 & 1721 \\
& $250-365$ & 1.99 & 541 \\
\hline
\end{tabular}

Figura 1. Riesgo relativo de desecho (RR) de la edad al primer parto en meses, con cuatro clases en ganado Holstein de México

Figure 1. Relative culling risk (RR) in four categories of age (in months) at first parturition for Holstein cattle in Mexico

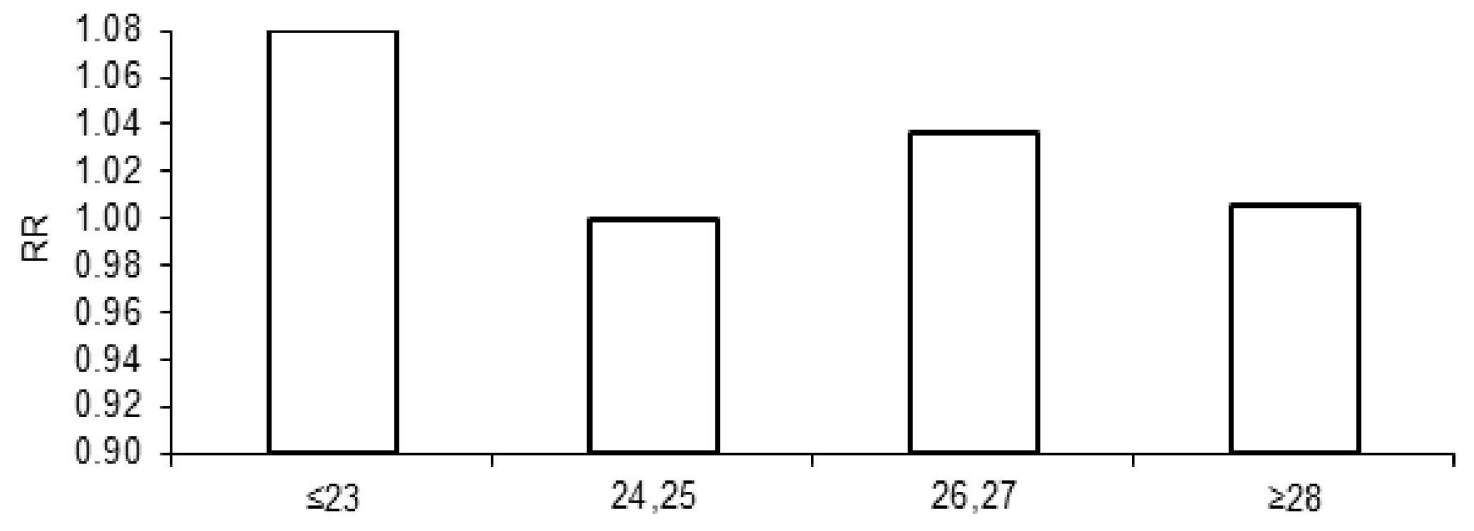

Age at first parturition 
Las proporciones y número de muertes detectadas dentro de cada FL y nivel de NPE se muestran en los Cuadros 1 y 2 respectivamente. Para las variables independientes incluidas en el modelo utilizado en este estudio, todos los efectos fueron significativos $(P<0.0001)$.

Para facilitar la interpretación de los efectos, los resultados se expresaron en riesgo relativo, bajo la influencia de efectos ambientales y genéticos, donde el riesgo promedio es 1 .

Las vacas más jóvenes (clase $1, \leq 23$ meses) presentaron un riesgo de desecho mayor que las clases 2, 3 y 4; la edad al primer parto no parece tener un efecto sobre la DVPF (Cuadro 1, Figura 1).

El efecto del nivel de producción estandarizado se muestra en la Figura 2. Las vacas dentro de los niveles de producción 1,2 y 3 (vacas con menores producciones estandarizadas) tuvieron 49,5 y 2 veces mayor probabilidad de ser desechadas que una vaca promedio (clase 6) respectivamente, después de este nivel el riesgo tendió a disminuir, habiendo un incremento del
Standardized production level (SPL) data showed the cows in the lowest levels as more likely to be culled than a cow with an average SPL (categ. 6); this was 49 times more probable in SPL 1, 5 times greater in SPL 2 and twice as likely in SPL 3 (Table 2, Figure 2). Risk diminished in levels 7, 8 and 9, and then

Cuadro 2. Proporción y número de observaciones dentro de cada nivel de producción estandarizado (SPL)

Table 2. Proportion (\%) and number (N) of observations in each standardized production level (SPL)

\begin{tabular}{crc}
\hline SPL & $\%$ & $\mathrm{~N}$ \\
\hline 1 & 6.06 & 1648 \\
2 & 5.94 & 1616 \\
3 & 8.95 & 2434 \\
4 & 12.81 & 3482 \\
5 & 15.10 & 4105 \\
6 & 15.98 & 4343 \\
7 & 13.01 & 3536 \\
8 & 9.66 & 2626 \\
9 & 6.62 & 1801 \\
10 & 5.86 & 1594 \\
\hline
\end{tabular}

Figura 2. Riesgo relativo (RR) de desecho para los niveles de producción estandarizados (SPL), con 10 clases: la clase 1, representa el nivel de producción más bajo y la clase 10 el nivel más alto

Figure 2. Relative culling risk (RR) in ten standardized production levels (SPL); 1 is lowest production level and 10 is highest

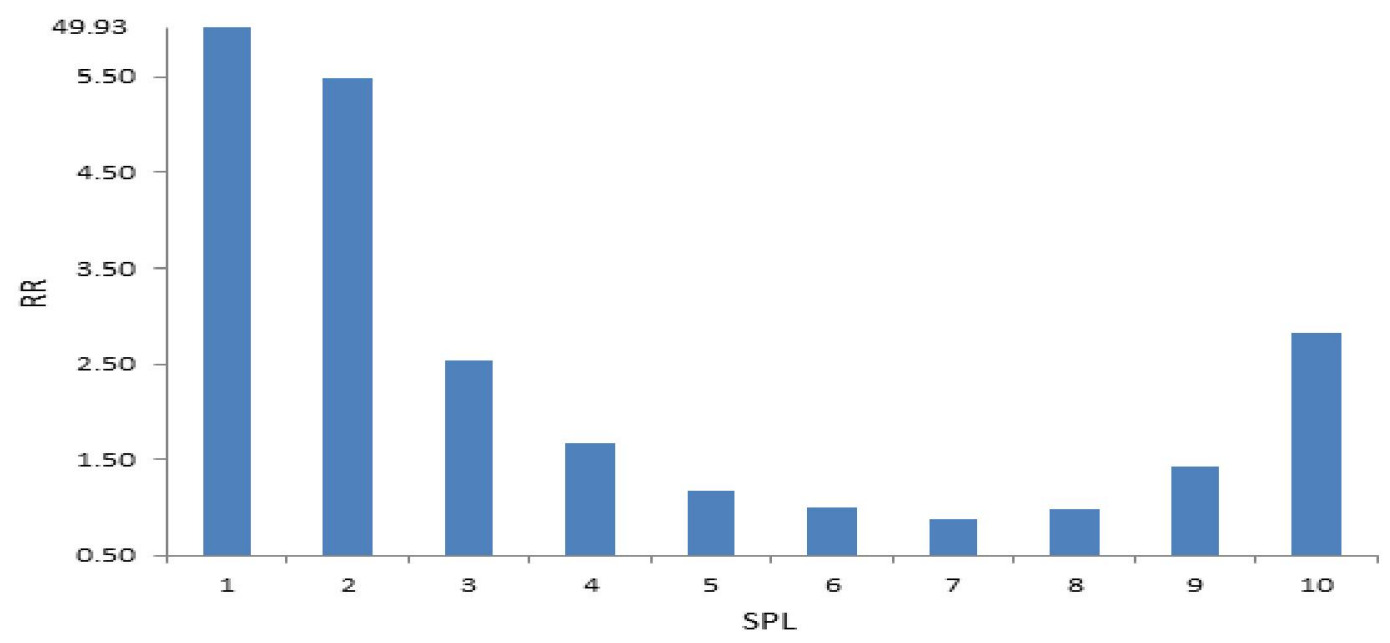


José R. Abadía Rojas, et al. / Rev Mex Cienc Pecu 2016;7(1):1-14

riesgo en el nivel 10, que corresponde a los animales más altos productores.

El efecto de la fase de la lactación se muestra en la Figura 3, en una vaca con lactancias consecutivas. Se puede observar que el riesgo de desecho tiende a incrementarse conforme transcurren los días en leche y el número de lactación, alcanzando su máximo a los 305 días después del parto e indicando un desecho intensivo durante la tercera fase.

El parámetro Rho (ñ) de la distribución de Weibull, las varianzas del padre y el parámetro gamma para el efecto hato-año de primer parto, la heredabilidad en las escalas logarítmica, original, efectiva y equivalente se presentan el Cuadro 3.

Los estimadores de los valores genéticos predichos variaron de -0.68 a 1.62 , con una media de cero. El riesgo relativo de desecho para DVPF de las hijas de los padres estudiados presentó un rango de 0.51 a 5.03. Valores genéticos negativos indicaron bajo riesgo de desecho para las hijas de un semental y por tanto, el incremento de su DVPF. increased in level 10, the most productive animals.

In cows with consecutive lactations, relative risk of discard tended to increase concurrently with milking days and lactation number, reaching a maximum of $305 \mathrm{~d}$ after parturition (Figure 3). The culling rate was particularly intense during the third lactation phase (LP; 250-305 d).

Cuadro 3. Parámetros genéticos estimados del análisis de supervivencia en ganado Holstein de México

Table 3. Estimated genetic parameters values for survival of Holstein cattle in Mexico

\begin{tabular}{ll}
\hline Parameters & Values \\
\hline$\rho$ & 2.37 \\
$\gamma$ Herd-birth year effect & 4.28 \\
$\sigma^{2}$ variance of father & 0.0395 \\
$h^{2}$ heritability, logarithmic scale & 0.08 \\
$h^{2}$ heritability, original scale & 0.13 \\
$h^{2}$ effective heritability & 0.12 \\
$h^{2}$ equivalent heritability & 0.10 \\
\hline
\end{tabular}

Figura 3. Riesgo relativo (RR) de desecho en las fases de lactación de un animal con lactancias consecutivas: lactaciones 1, 2, 3 y $\leq 4$ por tres fases de 0-29, 30-249 y 250-305 días

Figure 3. Relative culling risk (RR) in cows with consecutive lactations $(1,2,3$ and $\leq 4)$; each lactation is divided into three phases $(0-29,30-249$ and 250-305 d)

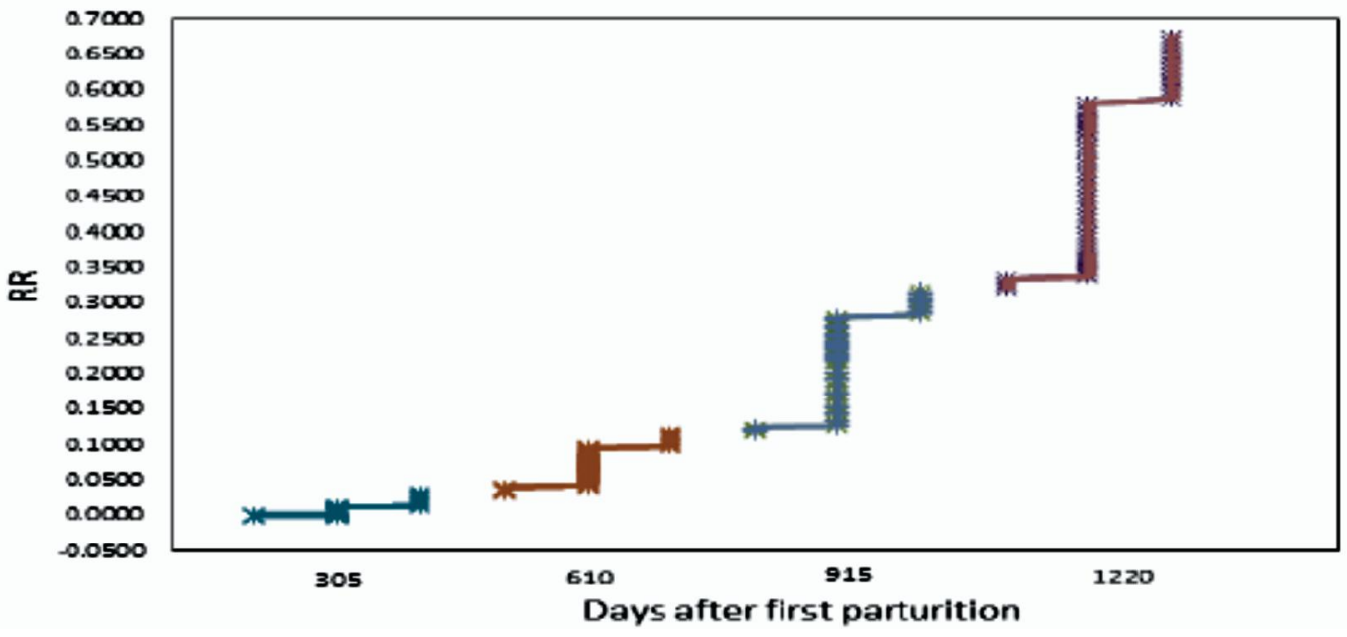


En los 2,800 padres analizados, la confiabilidad de los valores genéticos osciló entre 0 y 0.95 y 179 padres contaron con una confiabilidad mayor o igual a 0.50. En la Figura 4, se puede observar la distribución de las confiabilidades de los valores genéticos para los machos evaluados.

Las tendencias genéticas para DVPF de sementales Holstein mexicanos de acuerdo con su año de nacimiento se muestran en la Figura 5. Las tendencias mostraron un incremento del riesgo del año 1997 al 2002 y una ligera disminución del riesgo en el 2003.

\section{DISCUSIÓN}

El bajo promedio de número de lactaciones por vida obtenida en este estudio nos indica que a esta edad las vacas pudieran no haber llegado a expresar su máximo potencial de producción $(11,12,13)$, lo cual implica que son desechadas poco después que éstas han completado dos lactaciones, resultados similares fueron reportados por otros investigadores(14-17).
The estimators for the predicted genetic values varied from -0.68 to 1.62 , with a mean of zero. Relative risk of culling for FPL in the daughters of the studied sires ranged from 0.51 to 5.03 . Negative genetic values indicated a low cull risk for the daughters of a sire and consequently higher FPL. Among the 2,800 analyzed sires, genetic value reliability varied from 0 to 0.95 , with 179 sires having a level $\geq 0.50$ (Figure 4).

Genetic tendencies for FPL of the studied Mexican Holstein sires by birth year showed increasing risk from 1997 to 2003, followed by a slight decrease in 2003 (Figure 5).

\section{DISCUSSION}

Lactations per PL was low on average in the present data, suggesting that the cows had not yet expressed their maximum productive potential $(11,12,13)$. This implies that they were discarded shortly after completing two lactations, which coincides with previous reports(14-17).

The $25.5 \%$ censoring rate in the records due to incomplete data is within the 9.4 to $73.4 \%$

Figura 4. Distribución de las confiabilidades de los valores genéticos (GV) de los sementales en estudio de acuerdo con el número de hijas con observaciones completas

Figure 4. Genetic value (GV) reliabilities for studied sires based on number of daughters with complete records

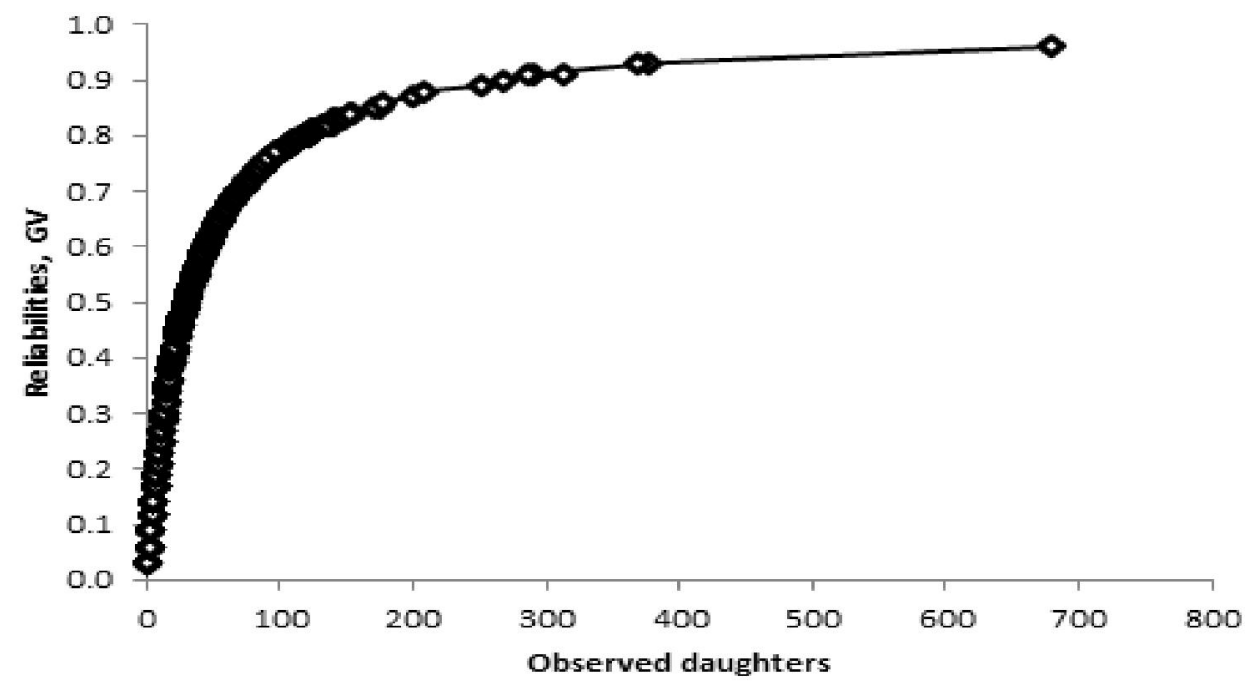


José R. Abadía Rojas, et al. / Rev Mex Cienc Pecu 2016;7(1):1-14

Figura 5. Tendencias genéticas para los valores genéticos estimados (EGV) para duración de vida productiva funcional en sementales Holstein mexicanos nacidos entre los años 1995 y 2003

Figure 5. Genetic trends of estimated genetic values (EGV) for length of functional productive life in Mexican Holstein sires born between 1995 and 2003

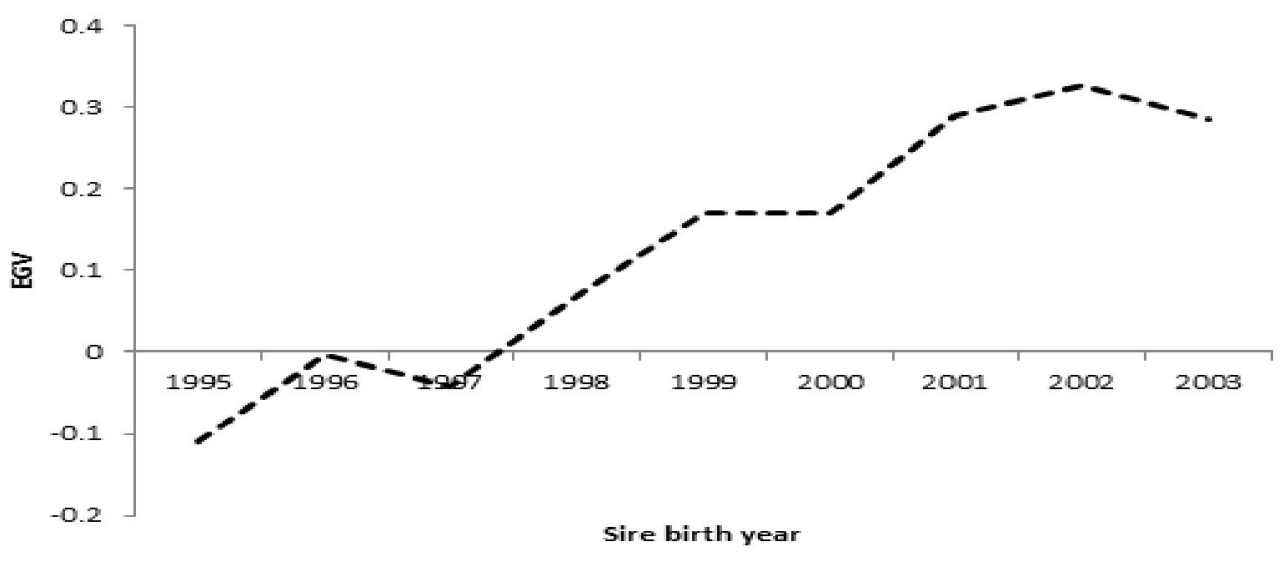

En este estudio, el $25.5 \%$ de los registros no contaba con información completa, es decir son datos censurados, lo cual se encuentra dentro del rango de 9.4 a $73.4 \%$, que reportan otros trabajos que usaron la misma metodología en poblaciones Holstein $(3,4,5)$.

Todos los efectos analizados en el modelo fueron importantes, teniendo NPE y FL una mayor contribución a la determinación del riesgo de desecho de un animal que la edad al primer parto, característica que no ha presentado en otras poblaciones una tendencia clara que explique el riesgo relativo de desecho de los animales $(4,11)$.

El efecto de la edad al primer parto mostró un ligero incremento en las vacas con partos $\leq 23$ meses, lo que se puede deber a que en este grupo se agruparon no sólo los animales que parieron a edades jóvenes por haber quedado gestantes antes de los 14 meses de edad, sino que además incluyó a vaquillas que no completaron los 9 meses en su primera gestación, pudiendo esto provocar problemas en los partos siguientes. Después de este límite, la edad al primer parto no tuvo efecto aparente sobre la DVPF, lo que resulta similar a los range reported in other studies using the same methodology in Holstein populations $(3,4,5)$.

All the effects analyzed in the model were significant $(P<0.0001)$, although SPL and LP made the greatest contribution to calculating culling risk. Age at first parturition made a lesser contribution. In other studies, this effect has not demonstrated a clear tendency to explain relative culling risk $(4,11)$. However, in the present data, it did show a slight increase in cows with first parturition at $\leq 23$ mo. This may be due to the fact that this group includes cows that gave birth at young ages because they were pregnant before 14 mo of age, as well as those that did not complete the full 9 mo of their first gestation, which can cause problems in later parturitions. In older age categories, age at first parturition had no apparent effect on FPL, as has been reported for other Holstein populations $(4,8)$.

Relative culling risk associated with standardized production levels (SPL) showed the lowest levels $(1,2$ and 3$)$ to have the highest risk. Voluntary culling in response to low SPL is clearly significant in this population. Previous studies done with data from the same population and 
resultados encontrados en otras poblaciones Holstein $(4,8)$.

Al analizar los riesgos relativos asociados con los niveles de producción, los mayores riesgos se presentaron en los niveles más bajos $(1,2$ y 3 ), indicando que el desecho voluntario por baja producción de leche es importante en esta población. Lo anterior coincide con otros estudios realizados anteriormente en la misma población y en otras poblaciones Holstein, donde los animales menos productivos presentaron incrementos en el riesgo de desecho $(4,11)$. Por otro lado, a partir del NPE 8, el riesgo incrementó ligeramente, sugiriendo que vacas altas productoras probablemente estén bajo un manejo fisiológico más intenso que las vacas menos productoras, lo que repercute sobre su $\operatorname{DVPF}(8,9)$.

Para las lactaciones analizadas, el riesgo de desecho en los últimos días de la lactación de una vaca con lactaciones consecutivas fue mayor, lo que no es sino un reflejo de las eliminaciones de las vacas no gestantes que ocurren al final de la lactación, lo que a su vez se puede deber a problemas reproductivos 0 de salud de la vaca(16,17). Estas tendencias de riesgo relativo de desecho son similares a los resultados publicados por Ducrocq ${ }^{(9)}$ y Chirinos et a(4), donde se observó un incremento de desecho al final de cada lactación. Es importante mencionar que por la manera en que se define la $\mathrm{FL}$, los primeros niveles de esta variable serán siempre más homogéneos que los últimos, ya que se van adicionando efectos de edad no contabilizada en el cálculo de vida productiva por los días en lactación superiores a 305 días, o a los periodos interparto que no se contabilizan con esta metodología.

El parámetro $\tilde{n}$ estimado en este estudio fue 2.37 y se encuentra dentro del rango de valores estimados en otras poblaciones Holstein que varían entre 0.36 a $5.0(4,9,10)$. Este resultado es coherente con lo observado, ya que un valor de $\rho$ superior a 1 , indica que el riesgo de desecho incrementa con la edad del animal. other Holstein populations also documented greater culling risk in less productive animals $(4,11)$. Risk also increased slightly beginning at SPL 8, suggesting that high producing cows experience more intense physiological stress than lower producers, which can affect their $\operatorname{FPL}(8,9)$.

Culling risk also increased in the final days of a lactation in cows with consecutive lactations. This reflects elimination of non-gestating cows at the end of lactation, possibly due to reproductive or health problems $(16,17)$. These tendencies coincide with previous studies reporting increased culling rates at the end of each lactation. The way LP is defined can influence these results since the first LP level will always be more homogeneous than the last ones. At later LP levels, age effects begin to accumulate but this are not included in calculation of the PL by days in lactation beyond $305 \mathrm{~d}$, nor in inter-parturition periods, which are not part of this methodology.

The estimated parameter was 2.37, a value within the 0.36 to 5.0 reported for other Holstein populations $(4,9,10)$. This value supports the recorded data since values greater than 1 indicate increased culling risk as animals age. The gamma parameter represents the variance within herd-year. Values greater than 1 indicate heterogeneity in culling practices(8). The 4.28 gamma value in the present study is similar to those reported in other Holstein populations $(3,4,13)$. Variation in culling practices may be related to varying levels of mechanization throughout Mexico, an aspect requiring further research.

Heritabilities in this study were 0.08 in the logarithmic scale, 0.13 in the original scale, 0.12 in the effective scale and 0.10 for equivalent heritability. All these are within published ranges: 0.02 to 0.11 for the logarithmic scale and 0.038 to 0.22 for the original scale $(3,4,8)$; and 0.048 to 0.108 for the effective and equivalent scales $(4,10,18)$. However, the estimators were higher than reported in a 
El parámetro gamma corresponde a la varianza dentro de cada hato-año y se considera que un valor mayor a 1 indica que existe heterogeneidad en las prácticas de desecho de los ganaderos(8). En este estudio el valor de gamma fue 4.28 , resultado que es similar al reportado en otras poblaciones Holstein $(3,4,13)$. Este resultado indica que las prácticas de desecho podrían estar relacionadas con diferentes niveles de tecnificación en diferentes partes de México, lo que deberá ser evaluado en futuros trabajos.

Las heredabilidades calculadas en este estudio fueron 0.08 en una escala logarítmica, 0.13 en la escala original, 0.12 en la escala efectiva y 0.10 para la heredabilidad equivalente. Estos valores están dentro del rango de los publicados por otros investigadores, los cuales han oscilado entre 0.02 y 0.11 cuando fueron expresados en una escala logarítmica y de 0.038 a 0.22 sobre una escala original $(3,4,8), 0.048$ a 0.108 para una escala efectiva y equivalente $(4,10,18)$. Sin embargo, los estimadores obtenidos fueron superiores a los reportados por un trabajo anterior en la misma población utilizando modelos lineales(7). Esta diferencia en las heredabilidades estimadas se debe a que el modelo de supervivencia del presente estudio fue superior para explicar los efectos ambientales, y en consecuencia aislar los efectos genéticos aditivos que están asociados con el carácter de interés, resultando ser mejor para estimar parámetros genéticos y predecir valores genéticos de DVPF. Los cálculos realizados con estos procedimientos dieron como resultado una heredabilidad similar a la que ha sido reportada en otros estudios $(8,10,18)$. Recientes investigaciones muestran extensiones de las fórmulas a otros modelos para los efectos genéticos de otras especies animales(19), que no dependen del parámetro $\tilde{n}$ y del valor extremo de la distribución, y que no se utilizan en este estudio.

La confiabilidad de los valores genéticos para los padres varió de 0.0 a 0.96 . Esta variabilidad se debe a que la confiabilidad de las predicciones previous study in the same population using linear models(7). These discrepancies in heritabilities occur because the survival model used in the present study is superior to previous models for explaining environmental effects. It can consequently isolate the additive genetic effects associated with the trait of interest, and is better for estimating genetic parameters and predicting FPL genetic values. Calculations done using these procedures produced heritability values similar to those reported elsewhere $(8,10,18)$. Recent research has demonstrated extensions of the formulas to other models for the genetic effects of other animal species(19). These do not depend on $\tilde{n}$ or the extreme value distribution, which was not used in the study.

Reliability of the sires' genetic values ranged from 0.0 to 0.96 . This variability is caused by the fact that the reliability of genetic predictions made using survival models is calculated based on the number of daughters with complete (observed) records and not a sire's total number of daughters. Because of this, younger sires may be at a disadvantage since most of their daughters will still be alive at the time of evaluation, substantially lowering prediction reliability $(8,9)$. The same reliability behavior has been reported in countries such as Spain, France and Switzerland $(4,10,11)$, where survival models help produce better predictors of sire FPL genetic values.

Sire FPL genetic values calculated based on daughter longevity in Mexico exhibited an increase in relative culling risk as sire birth year advanced. This increase implies an important decrease in genetic values that may be due to increased selection of sires by breeders for predicted transmission of improved milk production in recent years. Aimed at producing high milk production cows, has affected daughter FPL since high milk production is associated with shorter FPL, probably due to health and fertility problems, as observed in the present study. These genetic tendencies 
genéticas utilizando modelos de supervivencia se calcula con base en el número de hijas con observaciones completas y no a través del número total de hijas. Lo anterior puede representar una desventaja para los padres jóvenes, ya que es de esperase que la mayoría de sus hijas se encuentren vivas al momento de la evaluación y por ello la confiabilidad de su predicción genética sea muy baja $(8,9)$. Este comportamiento de las confiablidades es similar a lo reportado en otros países como España, Francia y Suiza $(4,10,11)$ donde, como en este estudio, los modelos de supervivencia permitieron obtener mejores predictores de los valores genéticos de los sementales para DVPF.

Los valores genéticos para DVPF de los sementales, calculados con base en la longevidad de sus hijas en México, mostraron un incremento en los riesgos relativos de desecho a medida de que el año de nacimiento de los mismos aumentaba. El incremento en el riesgo relativo implica la disminución de los valores genéticos y puede ser debida a que durante los últimos años, los ganaderos han seleccionado a los sementales por su habilidad de transmisión predicha para producción de leche, con el objetivo de tener vacas con altas producciones, y esto a la vez ha afectado la DVPF de las hijas, debido a que la alta producción de leche está asociada a cortas DVPF probablemente por problemas de salud 0 fertilidad como lo indican los resultados en este estudio. Estas tendencias genéticas son diferentes a las reportadas para países tales como Francia, Alemania y Canadá, donde se ha encontrado un descenso en el riesgo de desecho para las hijas de los sementales conforme avanza el tiempo, lo que se puede deber a que desde hace varios años, la característica de DVPF se ha incluido en los programas de mejoramiento genético(9-12).

\section{CONCLUSIONES E IMPLICACIONES}

La magnitud de las heredabilidades estimadas de 0.08 y 0.13 sobre una escala logarítmica y original, respectivamente, 0.12 y 0.10 para una differ from those reported for countries such as France, Germany and Canada where culling risk has declined over time for the daughters of Holstein sires. Most likely this is in response to inclusion of FPL in genetic improvement programs for many years $(9-12)$.

\section{CONCLUSIONS AND IMPLICATIONS}

The estimated heritabilities observed in the present study $(0.08$ for logarithmic scale; 0.13 for original scale; 0.12 for effective scale and 0.10 for equivalent scale) indicate that this trait can be effectively integrated into genetic improvement programs, as has occurred in other Holstein populations. The Weibull distribution and associated regression model adequately represented length of functional productive life for Holstein cattle in Mexico and are useful in calculating heritability and predicting genetic values for this trait.

\section{ACKNOWLEDGEMENTS}

The authors thank the Asociación Holstein de México, and Dr. Vincent Ducrocq and Dr. Zuleima Chirinos for assistance with the Survival Kit program. The research reported here forms part of the project "Aplicación de herramientas genómicas en el mejoramiento genético de la fertilidad del ganado Holstein productor de leche" (No. SIGI: 11402733072).

End of english version

escala efectiva y equivalente, respectivamente, indica que esta característica se puede integrar efectivamente a los programas de mejoramiento genético como se ha hecho en otras poblaciones de ganado Holstein, que pueden ser consideradas como elementos de selección indirecta para la duración de vida productiva 
José R. Abadía Rojas, et al. / Rev Mex Cienc Pecu 2016;7(1):1-14

funcional. La distribución de Weibull y el modelo de regresión asociado son adecuados para representar la duración de vida productiva funcional de ganado Holstein en México, y para calcular la heredabilidad y predecir valores genéticos para este carácter.

\section{AGRADECIMIENTOS}

Se agradece el apoyo a la Asociación Holstein de México y al Dr. Vincent Ducrocq y la Dra. Zuleima Chirinos por su ayuda y recomendaciones con el programa "Survival kit". El trabajo fue parte del proyecto "Aplicación de herramientas genómicas en el mejoramiento genético de la fertilidad del ganado Holstein productor de leche" No. SIGI: 11402733072.

\section{LITERATURA CITADA}

1. Ducrocq V, Quaas RL, Pollak EJ, Casella G. Length of productive life in dairy cows. 1. Justification of a Weibull Model. J Dairy Sci 1988;71:3061-3070.

2. Ducrocq V, Quaas RL, Pollak EJ, Cassella G. Length of productive life of dairy cows. 2. Variance component estimation and sire evaluation. J Dairy Sci 1988;71:30713079.

3. Sewalem A, Kistemaker GJ, Ducrocq V, Van Doormaal BJ. Genetic analysis of herd life in Canadian dairy cattle on a lactation basis using a Weibull proportional hazards model. J Dairy Sci 2005;88:368-375.

4. Chirinos Z, Carabaño MJ, Hernandez D. Genetic evaluation of length of productive life in the Spanish Holstein-Friesian population. Model validation and genetic parameters estimation. Livestock Sci 2007;106:120-131.

5. Roxström A, Ducrocq V, Strandberg E. Survival analysis of longevity in dairy cattle on a lactation basis. Genet Sel Evol 2003;35:305-318.

6. Ruíz LF, Oltenacu PA, Blake RW. Efecto del nivel de producción de leche sobre la duración de vida productiva en ganado Holstein de registro en México. Téc Pecu Méx 1994;32(3):105-112.

7. Valencia MP, Ruiz LF, Montaldo VH. Estimación de parámetros genéticos para características de longevidad y producción de leche en ganado Holstein de México. Interciencia 2004;(29):52-56.

8. Ducrocq V. Statistical analysis of length of productive life for dairy cows of the Normande breed. J Dairy Sci 1994;77(3):855-866.

9. Ducrocq V. Two years of experience with the French genetic evaluation of dairy bull on production - adjusted longevity of their daughter. Proc Inter Workshop in EU. Concerted action for Genetic Improvement of Functional Traits in Cattle (GIFT): Longevity. Jouy-en-Josas, Francia. Interbull Bulletin, 1999;21:60-68.

10. Ducrocq V. An improved model for the French genetic evaluation of dairy bulls on length of productive life of their daughters. Anim Sci 2005;80:249-256.

11. Vukasinovic N, Moll J, Casanova L. Implementation of a routine genetic evaluation for longevity based on survival analysis techniques in dairy cattle populations in Switzerland. J Dairy Sci 2001;84:2073-2080.

12. Dürr JW, Monardes HG, Cue RI. Genetic analysis of herd life in Quebec Holsteins using Weibull models. J Dairy Sci 1999;82:2503-2513.

13. Terawaki $Y$, Katsumi T, Ducrocq V. Development of a survival model with piecewise Weibull baselines for the analysis of length of productive life of Holstein cows in Japan. J Dairy Sci 2006;89:4058-4065.

14. Vitela MI, Cruz VC, Ramos PM. identificación de las causas de desecho en cinco establos lecheros de Aguascalientes México. Téc Pecu Mex 2004;42(3):437-444.

15. Bascom SS, Young AJ. A summary of the reasons why farmers cull cows. J Dairy Sci 1998;81:2299-2305.

16. Weigel KA, Palmer RW, Caraviello DZ. Investigation of factor affecting voluntary and involuntary culling in expanding dairy herds in Wisconsin using survival analysis. J Dairy Sci 2003;86:1482-1468.

17. Hare E, Norman HD, Wright JR. Survival rates and productive herd life of dairy cattle in the United States. J Dairy Sci 2006;(89):3713-3720.

18. Yazdi MH, Visscher PM, Ducrocq V, Thompson R. Heritability, reliability of genetic evaluations and response to selection in proportional hazard models. J Dairy Sci 2002;85:15631577.

19. Meszaros G, Pálos J, Ducrocq V, Sölkner J. Heritability of longevity in Large White and Landrace sows using continuous time and grouped data models. Genet Select Evol 2010:42:113. 